\title{
Article
}

Mycosphere

\section{Taxonomy of the south Brazilian species of Protostropharia (Strophariaceae, Agaricales)}

\author{
Seger $\mathrm{C}^{1^{*}}$, Gallego $\mathrm{JC}^{2}$, Takiuchi $\mathrm{E}^{2}$ and Cortez $\mathrm{VG}^{1,3}$ \\ ${ }^{1}$ Universidade Federal do Paraná, Programa de Pós-Graduação em Botânica, P.O. Box 19031, CEP 81531-980, \\ Curitiba-PR, Brazil. \\ ${ }^{2}$ Universidade Federal do Paraná, Programa de Pós-Graduação em Ciência Animal, Rua Pioneiro 2153, Jardim \\ Dallas, CEP 85950-000, Palotina-PR, Brazil. \\ ${ }^{3}$ Universidade Federal do Paraná, Departamento de Biodiversidade, Rua Pioneiro 2153, Jardim Dallas, CEP 85950- \\ 000, Palotina-PR, Brazil.
}

Seger C, Gallego JC, Takiuchi E and Cortez VG 2017 - Taxonomy of the south Brazilian species of Protostropharia (Strophariaceae, Agaricales). Mycosphere 8(8), 1044-1053, Doi 10.5943/mycosphere/8/8/5

\begin{abstract}
Three species of Protostropharia are reported in South Brazil: P. alcis ssp. austrobrasiliensis, $P$. dorsipora and $P$. semiglobata. Morphological variations are described and discussed for $P$. alcis ssp. austrobrasiliensis and $P$. dorsipora, as well sequences of the ITS region of rDNA, which were compared to other members of the genus. A key for the southern Brazilian species and photographs of macro- and microscopic features are furnished.
\end{abstract}

Key words - coprophilous agarics, fungal barcode, mycobiota, taxonomy

\section{Introduction}

Protostropharia Redhead, Moncalvo \& Vilgalys is a recently proposed genus in the Strophariaceae Singer \& A.H. Sm. (Redhead 2013). For many years, the species now placed in this genus were classified in subgenus or section Stercophila Romagn. ex Noordel. of Stropharia (Fr.) Quél., since they are coprophilous, present glutinous basidiomata, a poorly developed and glutinous annulus, dark purplish spore print, large basidiospores and presence of chrysocystidia (Singer 1986, Noordeloos 2011).

However, members of Protostropharia are distinguished from Stropharia due to lack of true acanthocytes, which are crystalline spiny cells, which cover the rhizomorphs or grows in cultured mycelium (Farr 1980). The presence of acanthocytes is considered a synapomorphic feature for Stropharia and has been documented by many researchers (Luo et al. 2006, Cortez \& Silveira 2008).

Thus, Protostropharia was recognized as an autonomous genus based on the presence of astrocystidia on basal mycelium (instead of true acanthocytes), which are short hyphae with globose and sharp apex with thick hyaline crystals, and also the glutinous basidiomata, smooth and thick-walled basidiospores with wide germ-pore (Redhead 2013).

Previous molecular studies just had indicated that coprophilous taxa were in fact distinct from Stropharia s.str. (Moncalvo et al. 2002) and the recently proposed genus has received good 
acceptance within mycologists (Kaur et al. 2013, Hahn 2014, Halama \& Kudławiec 2014, Wang \& Tzean 2015).

The present paper presents a review of the south Brazilian species of Protostropharia, as well a discussion on the taxonomy, distribution and phylogenetic relationships.

\section{Materials \& Methods}

\section{Collecting and morphological analysis}

Specimens were collected in areas of Atlantic Rainforest in the southern Brazilian States of Rio Grande do Sul, Santa Catarina and Paraná. Herbarium specimens from ICN, MBM and SMDB (Thiers 2016) were also examined. Color names and codes in the description of macroscopic features follow Kornerup \& Wanscher (1978). For microscopic examination, slides were mounted with 3\% KOH and 1\% Congo Red and dimensions were taken according to Halama \& Kudławiec (2014), with a Moticam ${ }^{\circledR} 2500$ camera in a Motic ${ }^{\circledR}$ trinocular microscope, by means of software Motic Image Plus $2.0^{\circledR}$. All collected specimens are preserved at the Herbarium of Campus Palotina, Universidade Federal do Paraná (HCP).

\section{DNA extraction, amplification and nucleotide sequencing}

DNA was obtained from five dried specimens of Protostropharia collected in Southern Brazil, for molecular analysis. The DNA extraction protocol described by De Hoog et al. (2005), modified by Balini et al (2015) was followed. The rDNA region ITS1-5.8S-ITS2 was amplified with primers ITS1-forward (5'-TCCGTAGGTGAACCTGCGG-3') and ITS4- reverse (5'TCCTCCGCTTATTGATATGC-3'), according to White et al. (1990). Polymerase chain reaction (PCR) amplifications were performed in a volume of $25 \mu \mathrm{L}$ containing $1 \times$ PCR reaction buffer (20 $\mathrm{mM}$ Tris- $\mathrm{HCl} \mathrm{pH} 8.4$ and $50 \mathrm{mM} \mathrm{KCl}$ ), $\mathrm{MgCl}_{2} 3 \mathrm{mM}$, dNTP mix 0,4 mM, $5 \mu \mathrm{M}$ of each primer and 1U Platinum Taq DNA polymerase (Invitrogen ${ }^{\circledR}$ ). Thermal cycles started at $94{ }^{\circ} \mathrm{C}$ for 5 minutes, followed by 25 cycles at $94{ }^{\circ} \mathrm{C}$ of 30 seconds, $56{ }^{\circ} \mathrm{C}$ of 45 seconds and $72{ }^{\circ} \mathrm{C}$ of 1 minute, and a final extension at $72{ }^{\circ} \mathrm{C}$ for 7 minutes.

PCR products $(\approx 630 \mathrm{bp})$ were analysed by $2 \%$ agarose gel electrophoresis in TBE buffer ( 89 $\mathrm{mM}$ Tris, $89 \mathrm{mM}$ boric acid, $2 \mathrm{mM}$ EDTA), $\mathrm{pH}$ 8.4, stained with ethidium bromide and visualized under UV light. The amplicons were quantified by NanoDrop and sequenced on ABI-Prism 3500 Genetic Analyzer (Applied Biosystems) in both directions using the forward and reverse primers.

\section{Phylogenetic analysis}

All generated sequences were initially evaluated in the program Phred/Phrap (http://asparagin.cenargen.embrapa.br/phph/) and edited manually using BioEdit sequence alignment editor version 7.2.5 (Hall 1999) simultaneously with FinchTV version 1.4 (http://www.geospiza.com/Products/finchtv.shtml), and deposited in GenBank database under the accession number KX686562 to KX686566. The homology of the sequences was compared with others sequences from database at GenBank by using BLAST (http://blast.ncbi.nlm.nih.gov/Blast.cgi).

Our sequences and more seven species of Strophariaceae at GenBank were aligned with ClustalW on BioEdit, which was also used to create a DNA identity matrix. Maximum likelihood (ML) phylogenetic tree was construct in MEGA version 7.0 (Kumar et al. 2016), employing the $\mathrm{GTR}+\mathrm{I}+\mathrm{G}$ model and bootstrap of 1000 replicates.

\section{Results}

\section{Phylogenetic analyses}

The maximum likelihood phylogenetic tree shows a clade formed by Protostropharia spp. (Fig. 1) which is well-supported with high bootstrap values (95\%). These results justify the placement of the south Brazilian specimens in the genus Protostropharia, as well supported the 
recognition of four distinct species in this study: $P$. alcis ssp. austrobrasiliensis, $P$. dorsipora, $P$. ochraceoviridis and $P$. ovalispora. All these species presented identity values between $0.927-0.991$ and smaller than 0.92 when compared to species belonging to other closely related genera, as Hypholoma and Stropharia s.str. In spite of the wide morphological variety, which will be discussed further, the specimens of P. alcis ssp. austrobrasiliensis HCP 905, 909, 910 and 912 exhibited high values $(>0.996)$ in the identity matrix, showing that all these are conspecific.

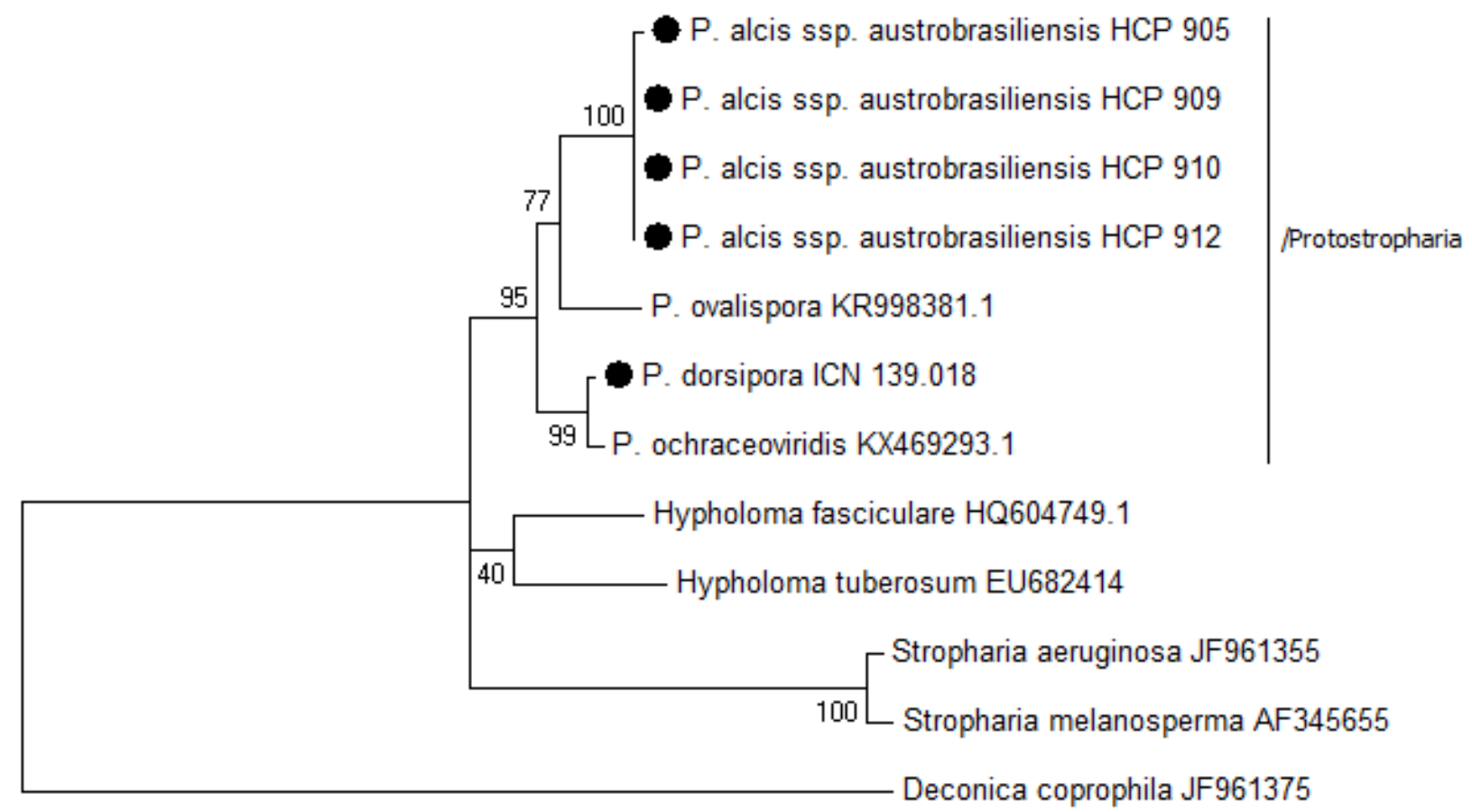

0.05

Figure 1 - Maximum likelihood phylogenetic tree of the ITS region of south Brazilian Protostropharia $(\bullet)$ and correlated species with their GenBank accession number. Bootstrap values are shown on branches.

\section{Taxonomy}

Protostropharia alcis ssp. austrobrasiliensis (Cortez \& R.M. Silveira) C. Hahn, Mycol. Bavar. 15: 28, 2014. Figs $2 \mathrm{a}-\mathrm{e}, 3 \mathrm{a}-\mathrm{j}$

Facesoffungi number: FoF 03367

Pileus 8-29 $\mathrm{mm}$, globose in young basidiomata becoming hemispheric to convex in age, sometimes with slight umbo, surface smooth and viscid-glutinous, margin smooth or translucentstriate, dark yellow (4C8) to olive yellow (3D8) in the centre, greyish yellow (2B5) toward the margin, and yellowish green (30A7-30B7) to greyish yellow (2C3) at margin. Context 1-2.2 mm, concolorous with the pileus, translucent appearance when wet, centrally thick and gradually thinner to the margin. Lamellae 2-5 mm, adnate, olive brown (4E3) to brownish grey (4E2), near, with white and serrate edge. Stipe 50-125 × 1-2.5 mm, central, cylindrical, smooth, viscid to glutinous surface, greyish yellow (4B3) to pale yellow (4A3). Veil forming an apical annulus, or often only an ephemeral and glutinous annular zone. Mycelium present on stipe base, without rhizomorphs. Pseudoesclerotia can be present on stipe base of some collections, but not in all examined specimens. Spore print brownish grey (7E2). 

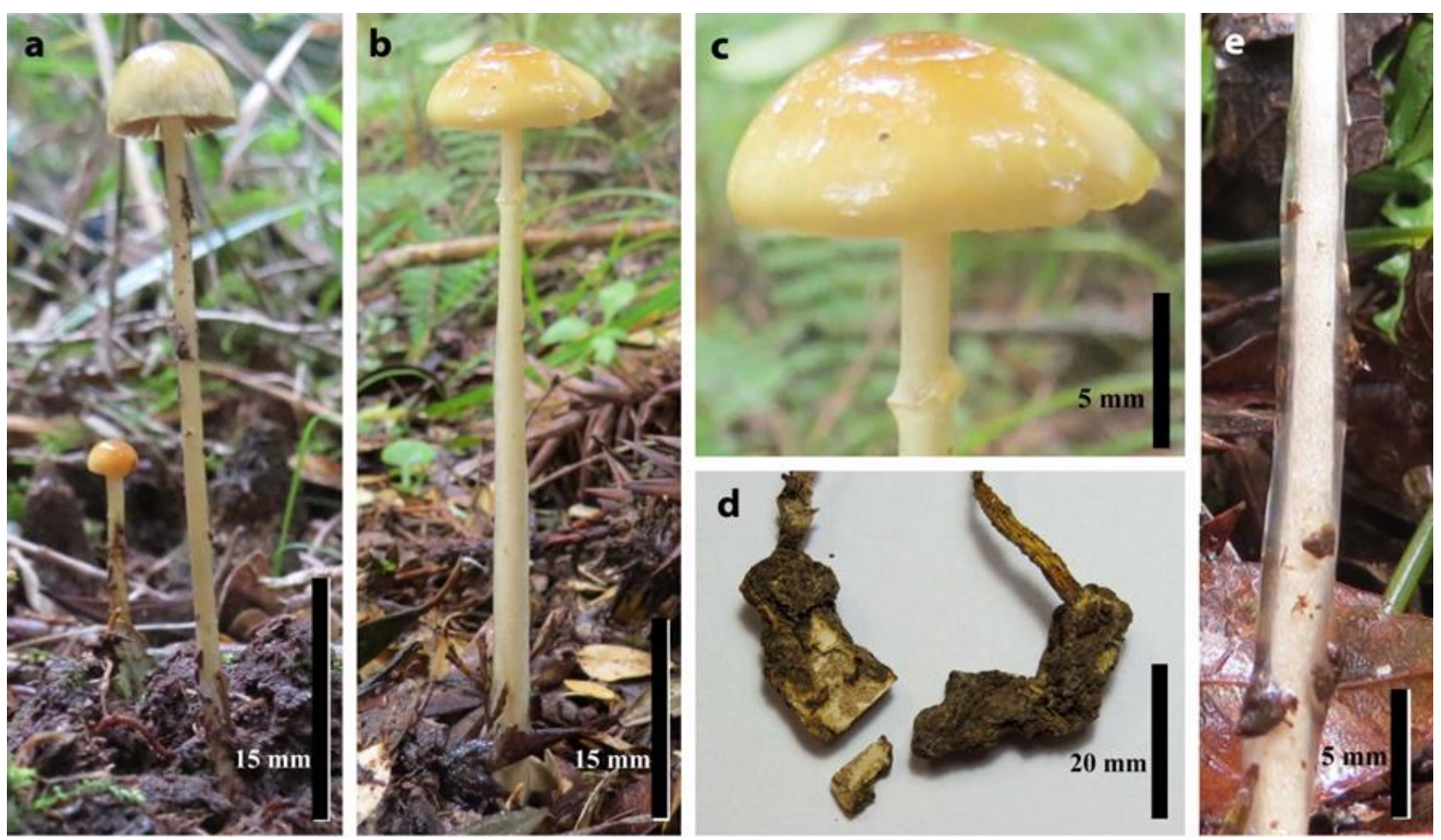

Figure 2 - Protostropharia alcis ssp. austrobrasiliensis - a-b. basidiomata; c. detail of pileus surface and stipe apex with glutinous annulus; d. pseudoesclerotia; e. detail of glutinous stipe. (a: HCP 906; b-c: HCP 909; d: HCP 904; e: HCP 911).

Basidiospores (10.5-) 11-14.5 (-15) × (6-) 6.5-9 (-9.5) $\mu \mathrm{m}, \mathrm{Q}=1.31-2.15, \mathrm{Q}_{\mathrm{m}}=1.65, \mathrm{n}=262$, ellipsoid to oblong in face and side-view, apically truncate by conspicuous and central germ pore, brown in $\mathrm{KOH}$, smooth and thick-walled. Basidia 23-39 × 7.5-14.5 $\mu \mathrm{m}$, clavate, some with slight constriction near at middle part, tetrasporic (rarely bisporic), sterigmata $\leq 8 \mu \mathrm{m}$, thin-walled, hyaline. Pleurocystidia $22.5-60.5 \times 8.5-18 \mu \mathrm{m}$, as chrysocystidia, fusiform, mucronate to rostrate apex $(\leq 10.5 \mu \mathrm{m})$, rounded apex present but are rare, thin-walled. Lamellae edge sterile. Cheilocystidia 17-42.5 × 3.5-10.5 $\mu \mathrm{m}$, as leptocystidia, sublageniform to flexuous-cylindrical, apex rounded, subcapitate or capitate, thin-walled, numerous on gill edge. Pileipellis two layered, comprising a suprapellis and subpellis. Suprapellis an ixotrichoderm, composed of cylindrical, anticlinally arranged, hyaline to yellowish, smooth or incrusted by yellowish spiraled pigment, thinwalled hyphae, 1-6 (-9) $\mu \mathrm{m}$ diam, immersed in a strongly gelatinized layer. Subpellis an ixocutis, composed of cylindrical, prostrate, yellowish hyphae, 2.5-22.5 $\mu \mathrm{m}$ diam. Pileus context formed by interwoven, hyaline to yellow in mass, smooth and thin-walled hyphae, 2.5-33 $\mu \mathrm{m}$ diam. Hymenophoral trama subregular to regular with thin-walled and hyaline hyphae, 3.5-22 (-29.5) $\mu \mathrm{m}$ diam. Subhymenium slightly gelanitized with inflated to subcellular hyphae. Caulocystidia 13$59.5 \times 3.5-12(-15.5) \mu \mathrm{m}$, as leptocystidia flexuous-cylindrical, apex rounded, subcapitate or capitate, thin-walled, similar to cheilocystidia. Stipitipellis gelatinized, with thin, loose, hyaline and thin-walled hyphae, 1.5-4 $\mu \mathrm{m}$ diam. Stipe trama with parallel, hyaline and thin-walled hyphae, 1.5$24 \mu \mathrm{m}$ diam. Chrysovessels present. Acanthocytes absent. Astrocystidia not found. Clamp connections present.

Distribution and habitat - South Brazil: known from the States of Paraná, Rio Grande do Sul and Santa Catarina. Solitary to scattered, growing on manure of cattle or horse, inside forest and in pastures. 

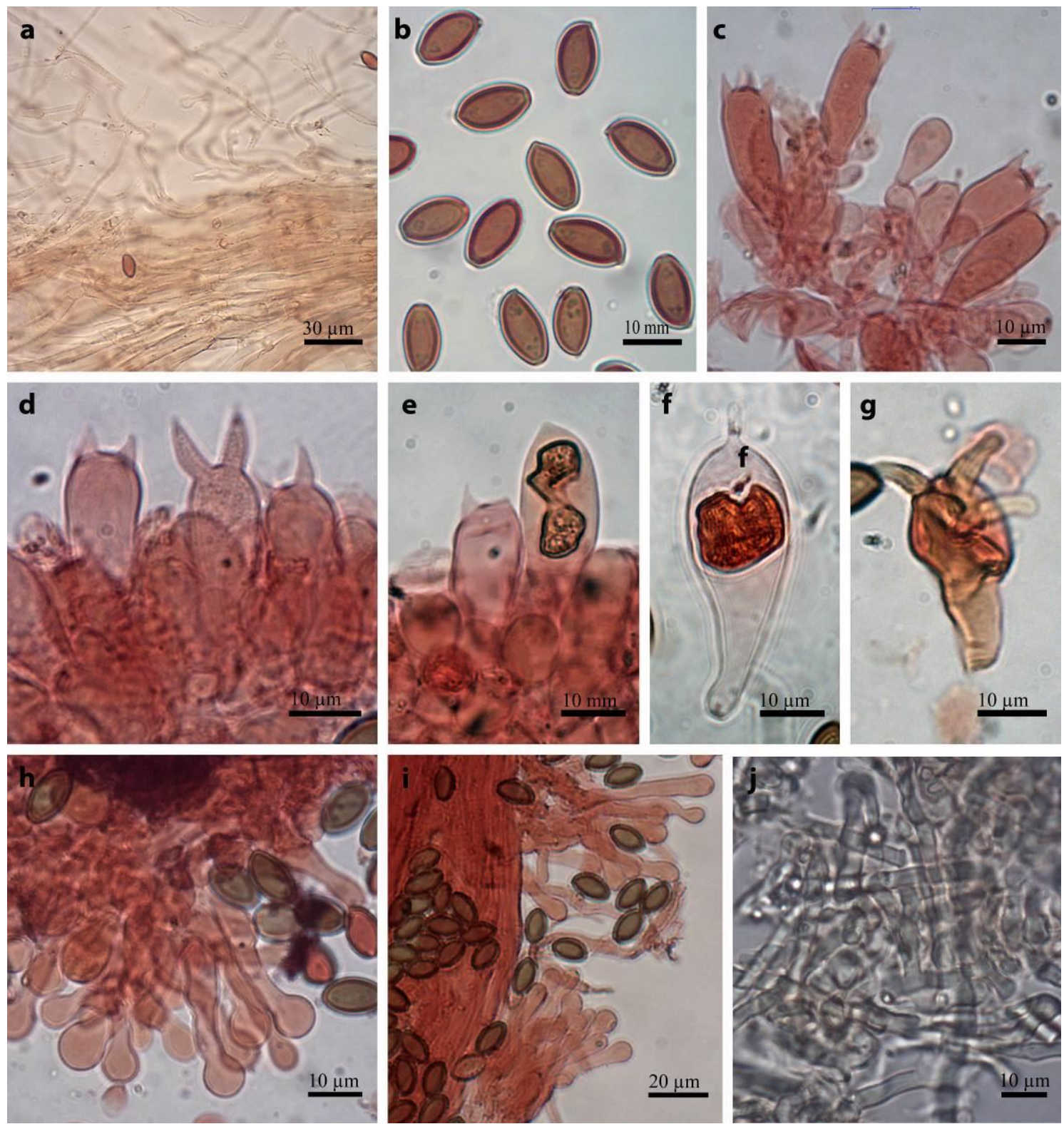

Figure 3 - Protostropharia alcis ssp. austrobrasiliensis - a. Pileipellis (supra- and subpellis); b. basidiospores; c-d. basidia; e-g. pleurocystidia; h. cheilocystidia; i. caulocystidia; j. pseudoesclerotium hyphae. (a-b: HCP 913; c; h-i: HCP 908; d: HCP 912; e: HCP 906; f: HCP 907; g: HCP 905; j: HCP 904).

Material examined - Brazil, Paraná State, Parque Marumbi, 19 March 1988, A.A.R. Meijer 1088 (MBM 325.995). Rio Grande Do Sul State, Rio Grande, 7 June 2008, V.G. Cortez 106/08 (HCP 916). Santa Maria, Distrito de Arroio do Só, Água Boa, 19 June 2003, V.G. Cortez 032/03 (SMDB 9.629); Morro da Caturrita, 23 April 2014, C. Seger \& G. Coelho 100 (HCP 904); C. Seger \& G. Coelho 101 (HCP 905); Morro do Elefante, 24 April 2004, V.G. Cortez 011/04 (ICN 139.002); Parque de Exposições UFSM, 10 April 2001, V.G. Cortez 017/01 (SMDB 9.541). Caçapava do Sul, Guaritas, 30 April 2005, V.G. Cortez 020/05 (ICN 139.103). Cambará do Sul, 2 April 2005, V.G. Cortez 007/05 (ICN 139.094). Capivari do Sul, Fazenda dos Touros, 28 May 2004, F. Caporal (ICN 139.034). Dom Pedro de Alcântara, 16 May 2009, P.S. Silva 216/09 (ICN 154.245). Viamão, Parque Estadual de Itapuã, Praia da Pedreira, 16 April 2005, M.A. Reck \& P.S. Silva 109/05 (ICN 139.083). Santa Catarina State, Água Doce, Fazenda Quiben, 24 February 2013, C. Seger 016 (HCP 664). Urubici, Parna São Joaquim, 11 June 2014, C. Seger \& C.R. Alves 129 (HCP 906); C. Seger \& C.R. Alves 130 (HCP 907); 12 June 2014, C. Seger \& C.R. Alves 140 (HCP 908); 20 February 2015, C.R. Alves 467 (HCP 912); 21 February 2015, C.R. Alves 473 (HCP 913); 22 April 2015, C. Seger \& C.R. Alves 170 (HCP 909); 23 April 2015, C. Seger \& C.R. 
Alves 181 (HCP 910); C. Seger \& C.R. Alves 183 (HCP 911). Vargem Bonita, Linha Coração, 18 March 2013, C. Seger 031 (HCP 666).

Additional material examined - Protostropharia alcis. Sweden, Dalarnas, St. Kopparberg, 20 September 1980, S. Jacobsson (ICN). Protostropharia luteonitens Sweden, Värmland, 21 September 1977, S. Jacobsson (ICN).

Notes - Stropharia alcis was originally described by Kytövuory (1999) from Boreal Region of Europe, where it grows on elk dung. Cortez \& Silveira (2008) identified the fungus as morphologically identical to European material (compared to Swedish material cited above), but considering the type of substrate (cow or horse dung) and the strongly disjunct distribution, they proposed as a new variety of that species. We examined the Swedish specimen of S. alcis again, and now we found caulochrysocystidia, which were not reported in the available descriptions of the species (Kytövuori 1999, Noordeloos 2011, Halama \& Kudławiec 2014).

Halama \& Kudławiec (2014) examined collections of P. alcis from Poland and concluded that size and color of the basidiomata are much variable in this species, depending on the amount of studied collections, climatic factors and developmental stage. In the same way, P. alcis ssp. austrobrasiliensis is widely represented in southern Brazil, where we had also noted a wide morphological variation, including occasional production of pseudoesclerotium, scattered bisporic basidia and pleurocystidia with forked or triple rostrate apex. Before performing molecular analysis, it was presumed that these variations could be taxonomically significant, however ITS data showed all these collections belong to a single species (Fig. 1).

The production of pseudosclerotium is described in P. tuberosa (Beardslee) Redhead (Redhead \& Kroeger 1987), and this feature is the most significant to distinguish it from P. alcis ssp. austrobrasiliensis (as well other species in the genus), once both present strong similarities in their macro- and microscopic features. Unfortunately, P. tuberosa seems to be a rare and poorly known species, whose neotype from North Carolina, USA is the only preserved specimen to our knowledge; future new collections of this species will allow improving the knowledge on its morphology and phylogenetic relationships within the genus.

Bisporic basidia are reported in P. luteonitens (Fr.) Redhead, which differs from P. alcis ssp. austrobrasiliensis by the larger basidiospores $(16-21 \times 9.5-12 \mu \mathrm{m})$ and absence of pleurocystidia (Kytövuory 1999). On the other hand, the pleurocystidia with 2-3 rostri at the apex is not reported in the checked literature on the group; however, this condition was noted only in a single collection (HCP 905).

Some new taxa recently described share some morphological similarities, especially the basidiospores, and are compared as follows. Protostropharia alcis ssp. punjabensis (A. Kaur, Atri $\&$ M. Kaur) C. Hahn was described as a variety of $P$. semiglobata with shorter basidiospores, but Hahn (2014) considered it also as a subspecies of $P$. alcis, growing on cow dung in India, with small differences on cystidia and pileus color. Kaur et al. (2013) reported bisporic basidia in Indian specimens, which were also observed in a single southern Brazilian specimen (HCP 912).

Another recently described species, P. ovalispora Wang \& Tzean from Taiwan, has same shape and surface (viscid to glutinous) of the pileus and stipe, and similar pleurochrysocystia, cheiloleptocystia and cauloleptocystia. It differs by more robust basidiomata (pileus with 20-60 $\mathrm{mm}$ and stipe up to $110 \times 6 \mathrm{~mm})$, slightly bigger $(12.0-15.5 \times 7.2-10.7 \mu \mathrm{m})$ and broadly ellipsoid to oval $\left(\mathrm{Q}_{\mathrm{m}}=1.53\right)$ basidiospores, and also has chrysocystidia on stipe apex and occasionally on gill edges too (Wang \& Tzean 2015).

Psilocybe parvula Y.S. Chang \& A.K. Mills, from Tasmania is possibly a Protostropharia, due to coprophilous substrate, glutinous pileus and stipe, and presence of chrysocysyidia (Chang et al. 2006). The basidiospores come close to P. alcis subs. austrobrasiliensis (12.9-15.4 × 7.5-9.2 $\mu \mathrm{m}$ in. Ps. parvula), cheilocystidia are similar in shape and size, and epicutis with gelatinized layer. Caulocystidia are not described in that species, but in comparison with Brazilian materials, the pileus is more orange brown and the substrate is wallaby dung, which can suggest a more specific substrate (Chang et al. 2006). 
Protostropharia alcis ssp. austrobrasiliensis is also similar to S. silvatica A.H. Sm., a name used by Meijer (2006, 2010) for specimens from Paraná, Brazil, since they have the same basidiospore size, but cheilocystidia are chrysocystidia and the mushroom is reported to grow solitary on cedar and hemlock (Smith 1941).

Hypholoma ericaeum (Fr.) Kühner, another common species in South Brazil, can be sometimes confounded with $P$. alcis ssp. austrobrasiliensis, since it is occurring in the same environments, has similar shape and colors of the basidiomata, as well as the basidiospores of similar size and shape. However, H. ericaeum is not coprophilous; the basidioma is dry, pileipellis not gelitinized and does not produces acanthocytes or astrocystidia (Cortez \& Silveira 2007).

Protostropharia alcis ssp. austrobrasiliensis is known from Brazil, in the States of Paraná (Meijer 2006) and Rio Grande do Sul (Silva et al. 2012), and now we recorded for the first time from Santa Catarina State.

Protostropharia dorsipora (Esteve-Rav. \& Barrasa) Redhead, Index Fung. 158: 1, 2014. Fig. 4a-i Facesoffungi number: FoF 03371

Pileus 10-17 mm, globose in young basidiomata becoming hemispheric to convex in age, smooth, brownish orange (5C5) to light brown (6D8), can be light orange (5C5) at margin. Context $2 \mathrm{~mm}$, greyish yellow (4B4), thicker in the centre and gradually thinner to the margin. Lamellae 3$4 \mathrm{~mm}$, adnate, brown (6E6) to dark brown (6F4), near, whitish edge. Stipe 40-48 $\times 1-2.5 \mathrm{~mm}$, central, cylindrical, smooth, evidence of viscid to glutinous surface by stuff glued on this, greyish yellow (4B4). Veil forming an apical annulus, that may be absent on dry materials. Rhizomorphs absent. Pseudoesclerotia absent. Spore print not seen.

Basidiospores (14-) 15-20 (-21.5) $\times 8-11 \mu \mathrm{m}, \mathrm{Q}=1.58-2.13, \mathrm{Q}_{\mathrm{m}}=1.80, \mathrm{n}=62$, oblong in face and side-view, apically truncate by broadly $(\leq 2.5 \mu \mathrm{m})$ and eccentric germ pore, brown in $\mathrm{KOH}$, smooth and thick-walled $(\leq 1 \mu \mathrm{m})$. Basidia $24-38 \times 9-13.5 \mu \mathrm{m}$, broadly clavate or subcylindrical with constriction near at middle part, tetrasporic, sterigmata $\leq 6.5 \mu \mathrm{m}$, thin-walled, hyaline. Pleurocystidia 33-54 × 10-15.5 $\mu \mathrm{m}$, as chrysocystidia, fusiform, with acute, mucronate or rostrate apex, rostrum $\leq 8 \mu \mathrm{m}$, thin-walled, scattered on gill side. Lamellae edge sterile. Cheilocystidia 25.5$57.5 \times 4-8 \mu \mathrm{m}$, as leptocystidia, sublageniform to flexuous-cylindrical, rounded apex, thin-walled, abundant on gill edge. Pileipellis two layered, comprising a suprapellis and subpellis. Suprapellis an ixocutis, composed of prostrate to interwoven, cylindrical, hyaline, smooth and thin-walled hyphae, 1-2 $\mu \mathrm{m}$ diam, immersed in gelatinized layer up to $85 \mu \mathrm{m}$. Subpellis with prostrate to interwoven, cylindrical, hyaline to yellow in mass hyphae, wider than the suprapellis hyphae (2.5-5 $\mu \mathrm{m}$ diam). Pileus context formed by interwoven, hyaline smooth and thin-walled hyphae, some inflated, 5-13 $\mu \mathrm{m}$ diam. Hymenophoral trama subregular to regular with thin-walled and hyaline hyphae, 5-11.5 $\mu \mathrm{m}$ diam. Subhymenium slightly gelatinized with subcellular hyphae. Caulocystidia $15-72.5 \times 4-7.5(-11.5) \mu \mathrm{m}$, as leptocystidia flexuous-cylindrical, rounded to subcapitate apex, thin-walled. Stipitipellis with prostrate, little gelatinized, hyaline, thin-walled and fine hyphae (1.5$5 \mu \mathrm{m}$ diam). Stipe trama with parallel, hyaline and thin-walled hyphae, 4.5-20 $\mu \mathrm{m}$ diam. Chrysovessels not found. Acanthocytes absent. Astrocystidia not found. Clamp connections abundant.

Distribution and habitat - Widespread in Europe (Noordeloos 2011); reported in Asia (Bau \& Meng 2008), North (Noordeloos 2011) and Southern America (only in Brazil). Solitary to scattered, growing on manure of cattle or horse, both inside forest and in pastures.

Material examined - Brazil, Paraná State, Curitiba/São José dos Pinhais, Reserva Biológica Cambui, 2 December 1979, A.A.R Meijer 153 (MBM 324.078, as S. semiglobata). Rio Grande do Sul State, Encruzilhada do Sul, Fazenda Xafri, 10 July 2004, V.G. Cortez 039/04 (ICN 139.018); V.G. Cortez 041/04 (ICN 139.020). Santa Maria, Colégio Politécnico UFSM, 3 March 2009, G. Coelho (HCP 914, specimen lost, only microscopic slide preserved).

Additional material examined - Protostropharia dorsipora. Sweden. Småland: Femsjö, 25 September 1959, F. Karlvall (ICN).

Notes - This is the only Protostropharia with basidiospores presenting an eccentrical germpore, being the diagnostic feature of $P$. dorsipora (Esteve-Raventós \& Barrasa 1995, Noordeloos 
2011). However, this feature may be easily overlooked if basidiospores are not accurately examined; for this reason, this mushroom has been misidentified, especially as $P$. semiglobata by many authors. When analyzing Bavarian collection, Hahn (2014) described some astrocystidia in basal mycelium that involved the substrate, but this structure was not found in our materials.

This mushroom seems to have some preference for horse dung (Noordeloos 2011, Hahn 2014), but Brazilian specimens also grows on cow dung. In Brazil, it is reported in Rio Grande do Sul State and is a new record from Paraná State.
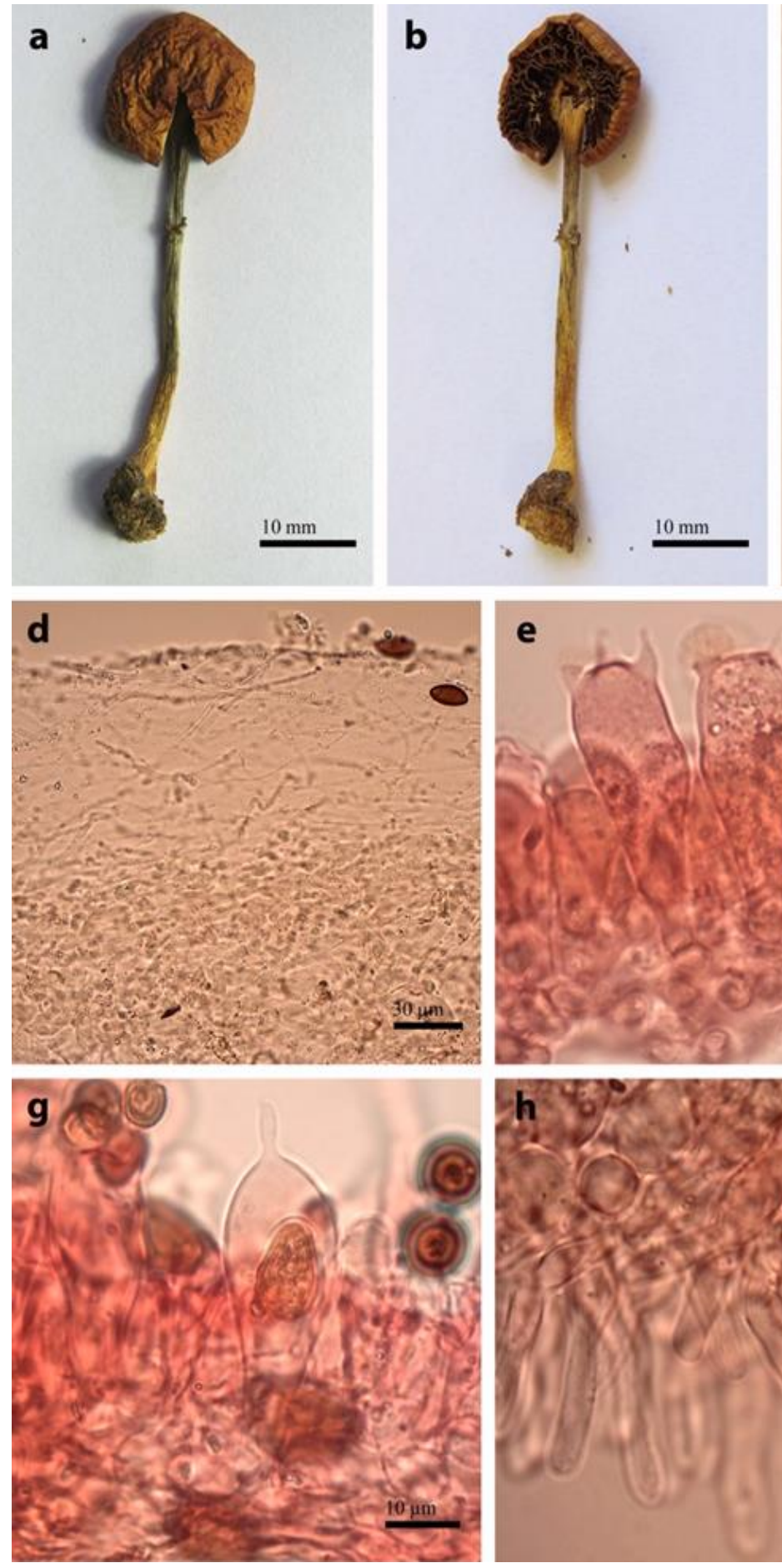
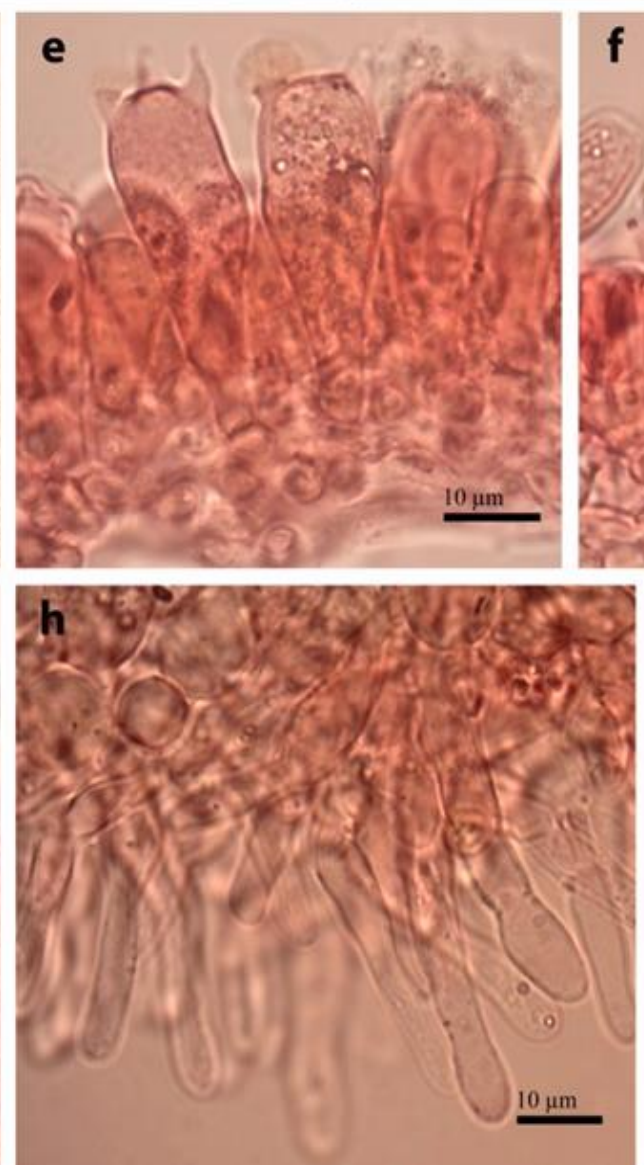
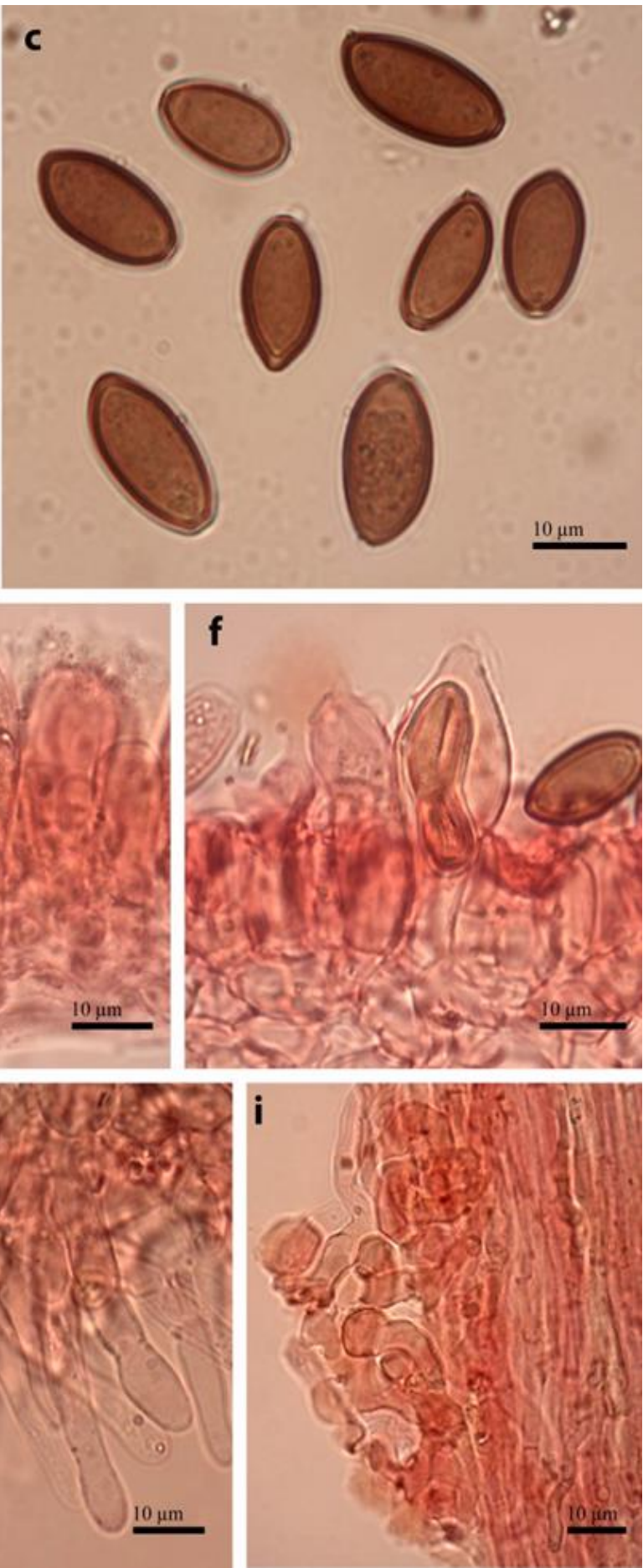

Figure. 4 - Protostropharia dorsipora - a-b. basidiomata; c. basidiospores; d. pileus surface; e. basidia; f-g. pleurocystidia; h. cheilocystidia; i. caulocystidia. All from ICN 139.020. 


\section{Other recorded species:}

Protostropharia semiglobata (Fr.) Redhead, Moncalvo \& Vilgalys.

Description: see Cortez \& Silveira (2008).

Notes - Protostropharia semiglobata has pale yellow basidiomata, small pileus (<30 mm), long stipe $(<120 \mathrm{~mm})$, large basidiospores $(16-21 \times 8.5-11 \mu \mathrm{m})$, and, probably, has a worldwide distribution, growing on herbivorous dung (Noordeloos 2011). Misidentifications as P. semiglobata are due to similarities with $P$. dorsipora, whose main difference is with the germ-spore central rather than eccentric of the latter, as previously discussed. In Brazil, P. semiglobata was reported from the States of Paraná (Meijer 2006) and Rio Grande do Sul (Cortez \& Silveira 2008). Examination of the material from Paraná resulted in re-determination as P. dorsipora (MBM 324.078); on the other hand, Cortez \& Silveira (2008) reported two collections from Rio Grande do Sul, one was lost and another from Rick's herbarium, which was not checked again. Thus, new new collections of this species are needed to assure its occurrence in Southern Brazil.

\section{Key to the Brazilian species of Protostropharia}

1. Basidiospores up to $15 \times 9 \mu \mathrm{m}$, occasionally forming pseudoesclerotia.

P. alcis ssp. austrobrasiliensis

1. Basidiospores larger than $15 \times 8 \mu \mathrm{m}$, never forming pseudoesclerotia.

2. Germ-pore central in face and side-view P. semiglobata

2. Germ-pore distinctly eccentric in side-view. .P. dorsipora

\section{Acknowledgements}

We thank the curators of the herbaria ICN, MBM and SMDB for loaned specimens, the Conselho Nacional de Desenvolvimento Científico e Tecnológico (CNPq, Proc. 483455/2013-3) and Fundação Araucária de Apoio ao Desenvolvimento Científico e Tecnológico do Estado do Paraná (Conv. 675/2014) for partially funding this research, and the Coordenação de Aperfeiçoamento de Pessoal de Nível Superior (CAPES) for Msc. scholarship given to the first author.

\section{References}

Balini LC, Luis AS, Soares LC, Vendruscolo ECG, Fiorini A. 2015 - Identificação pela técnica de PCR-RFLP de Aspergillus spp. isolados de grãos de soja e milho. Revista Brasileira de Energias Renováveis 4, 83-99.

Bau T, Meng T. 2008 - Strophariaceae of China (II): Stropharia. Journal of Fungal Research 6, 734.

Chang YS, Gates GM, Ratkowsky DA. 2006 - Some new species of the Strophariaceae (Agaricales) in Tasmania. Australasian Mycologist 24, 53-68.

Cortez VG, Silveira RMB. 2007 - Species of Hypholoma (Fr.) P. Kumm. (Strophariaceae, Agaricales) from Rio Grande do Sul State, Brazil. Acta Botanica Brasilica 21, 609-621.

Cortez VG, Silveira RMB. 2008 - The agaric genus Stropharia (Strophariaceae, Agaricales) in Rio Grande do Sul State, Brazil. Fungal Diversity 32, 31-57.

De Hoog GS, Göttlich E, Platas G, Genilloud O et al. 2005 - Evolution, taxonomy and ecology of the genus Thelebolus in Antartica. Studies in Mycology 51, 33-76.

Esteve-Raventós F, Barrasa JM. 1995 - Coprophilous Agaricales from Spain II. The genus Stropharia and Stropharia dorsipora sp. nov. Revista Iberoamericana de Micología 12, 70-72.

Farr DF. 1980 - The acanthocyte, a unique cell type in Stropharia (Agaricales). Mycotaxon 11, 241-249. 
Hahn C. 2014 - Ein bayerischer Nachweis von Protostropharia dorsipora mit Anmerkungen zur Gattung Protostropharia und kommentiertem Bestimmungsschlüssel. Mycologia Bavarica15, $19-32$.

Halama M, Kudławiec B. 2014 - New localities of Protostropharia alcis (Basidiomycota, Agaricales) in Poland. Acta Mycologica 49, 47-57.

Hall TA. 1999 - BioEdit: a user-friendly biological sequence alignment editor and analysis program for Windows 95/98/NT. Nucleic Acids Symposium Series 41, 95-98.

Kaur A, Kaur M, Atri, NS. 2013 - Protostropharia alcis subsp. punjabensis: a new coprophilous agaric from India. Kavaka 41, 11-14.

Kornerup A, Wanscher JH. 1978 - Methuen Handbook of Colour. $3^{\text {rd }}$ ed. London: Eyre Methuen.

Kumar S, Stecher G, Tamura K. 2016 - MEGA7: Molecular Evolutionary Genetics Analysis version 7.0 for bigger datasets. Molecular Biology and Evolution 33, 1870-1874.

Kytövuory I - 1999. The Stropharia semiglobata group in NW Europe. Karstenia 39, 11-32.

Luo H, Li X, Li G, Pan Y, Zhang K. 2006 - Acanthocytes of Stropharia rugosoannulata function as a nematode-attacking device. Applied and Environmental Microbiology 72, 2982-2987.

Meijer AAR. 2006 - Preliminary list of the macromycetes from the Brazilian state of Paraná. Boletim do Museu Botânico Municipal 68, 1-55.

Meijer AAR. 2010 - Preliminary list of the macromycetes from the Brazilian state of Paraná: corrections and updating. Boletim do Museu Botânico Municipal 72, 1-9.

Moncalvo JM, Vilgalys R, Redhead SA, Johnson JE et al. 2002 - One hundred and seventeen clades of euagarics. Molecular Phylogenetics and Evolution 23, 357-400.

Noordeloos ME. 2011 - Strophariaceae s.l. Fungi Europaei 13. Alassio: Edizioni Candusso.

Redhead SA. 2013 - Nomenclatural novelties. Index Fungorum 15, 1-2.

Redhead SA, Kroeger P. 1987 - A sclerotium-producing Hypholoma from British Columbia. Mycotaxon 29, 457-465.

Silva PS, Cortez VG, Silveira RMB. 2012 - Synopsis of the Strophariaceae (Basidiomycota, Agaricales) from Floresta Nacional de São Francisco de Paula, Rio Grande do Sul State, Brazil. Hoehnea, 39, 479-487.

Singer R. 1986 - The Agaricales in Modern Taxonomy. $4^{\text {th }}$ ed. Koeltz, Koenigstein.

Smith AH. 1941 - Studies of North American Agarics - I. Contributions from the University of Michigan Herbarium 5, 1-73.

Thiers B. 2016 (continuously updated) - Index herbariorum: a global directory of public herbaria and associated staff. New York Botanical Garden's virtual herbarium. Available at: http://sweetgum.nybg.org/science/ih/. Accessed on 29 Dez 2016].

WangY-W, Tzean S-S. 2015 - Dung-associated, potentially hallucinogenic mushrooms from Taiwan. Taiwania 60, 160-168.

White TJ, Bruns T, Lee S, Taylor J. 1990 - Amplification and direct sequencing of fungal ribosomal RNA genes for phylogenies. In: Innis MA, Gelfand DH, Sninsky JJ, White TJ (eds.) PCR protocols: a guide to methods and applications. San Diego: Academic Press. Pp. $315-322$. 